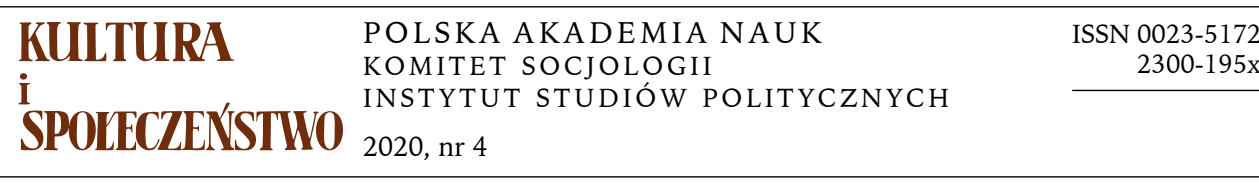
$\begin{array}{llllllllllll}A & R & T & Y & K & U & Ł & Y\end{array}$
I
$\begin{array}{llllllll}\mathrm{R} & \mathrm{O} & \mathrm{Z} & \mathrm{P} & \mathrm{R} & \mathrm{A} & \mathrm{W} & \mathrm{Y}\end{array}$

MICHA£ DĄBROWSKI

Instytut Studiów Politycznych PAN

Akademia Pedagogiki Specjalnej im. Marii Grzegorzewskiej w Warszawie

\title{
CZY MIŁOŚĆ ROMANTYCZNA JEST EMOCJĄ?
}

\section{WSTĘP}

Miłość interpersonalna jest jednym z najbardziej złożonych, wielowarstwowych zagadnień opisywanych w naukach społecznych. W kulturze zachodnioeuropejskiej jedna $z$ najogólniejszych klasyfikacji tego pojęcia to etymologiczny podział, wywodzący się z języka starogreckiego, na pięć terminów odpowiadających pięciu rodzajom miłości. Są to: agape (miłość Boga do człowieka, miłosierdzie), philia (miłość braterska, przyjaźń), storge (miłość rodzinna, bazująca na zaangażowaniu), xenia (gościnność) oraz eros (miłość erotyczna, namiętna, romantyczna). Erich Fromm (2018) wyróżnia miłość braterską, matczyną, ojcowską, erotyczną, miłość samego siebie oraz miłość do Boga. W Katechizmie Kościoła Katolickiego (2018) opisana jest miłość Boga do człowieka, której kulminacyjny punkt stanowi przyzwolenie Boga Ojca na śmierć syna, Jezusa Chrystusa, mającą odkupić grzechy popełniane przez ludzi, a Benedykt XVI (2006, s. 17) w encyklice O miłości chrześcijańskiej pisze: „Eros Boga do człowieka jest zarazem [...]

Autor dziękuje opiekunowi naukowemu prof. dr hab. Aleksandrowi Manterysowi oraz pomocniczemu opiekunowi naukowemu dr Iwonie Zielińskiej za wsparcie merytoryczne i pomoc redakcyjną.

Adres do korespondencji: dabrowskimichal476@gmail.com; 0000-0001-6369-3551 
agape”. Pojęcie miłości ma zatem bardzo złożoną zarówno etymologię, jak i konotację znaczeniową.

W dzisiejszych czasach, jak się wydaje, jeden z wymienionych rodzajów miłości wyróżnia się w dyskursie publicznym. Namiętność, uczuciowość, tęsknota za bliskością, nieprzewidywalność... określenia te nasuwają jedno skojarzenie. Czy bardzo pomyliłby się ten, kto stwierdziłby, że najsilniejsze emocje i pragnienia wywołuje miłość romantyczna? Książki romantyczne, filmy hollywoodzkie, przemysł muzyczny oraz publicystyka społeczno-obyczjowa bazują na wskazanych tematach oraz nieokreślonej bliżej wizji miłości romantycznej. Czym jednak jest owa miłość romantyczna?

Jedną z wielu koncepcji miłości romantycznej przedstawił Raja Halwani w książce Love, Sex and Mariage: An Introduction (2018). Według tego filozofa miłość romantyczna jest emocją podobną do radości, smutku, strachu czy złości. Zamierzam przyjrzeć się tu tej koncepcji z perspektywy głównych teorii i badań z obszaru socjologii miłości, które omówię na początku. Potem przejdę do omówienia koncepcji miłości romantycznej w polu etyki, by jeszcze mocniej zarysować jej zarówno mocne, jak i słabe strony.

\section{MIŁOŚĆ W SOCJOLOGII: PRZEGLĄD LITERATURY}

W Encyclopedia of Sociology przeczytamy, że doświadczamy miłości i wyrażamy ją w sposób zależny od kultury i subkultury, która nas ukształtowała. Autorzy zastrzegają jednak: „Pomimo różnic kulturowych niektóre aspekty miłości wydają się uniwersalne. Wszędzie miłość obejmuje cztery idee: dopasowanego partnera, emocjonalne doświadczenie kochania, mentalne doświadczenie albo proces myślowy kochania oraz działania między osobą kochającą i jej partnerem/partnerką uważane za akceptowane i spodziewane" (Borgatta, Montgomery 2000, s. 1698).

Maciej Gdula w książce Trzy dyskursy miłosne (2009) zwraca uwagę na cztery główne koncepcje miłości, które można odnaleźć w literaturze socjologicznej. Pierwsza to podejście socjobiologiczne, w którym miłość, w tym miłość romantyczna, rozumiana jest jako „epifenomen ewolucyjny". Podejście to, w rozumieniu Gduli, obejmuje również psychologię ewolucyjną. Moim zdaniem, można je jednak rozszerzyć na wszystkie nauki biologiczne, które patrzą na człowieka jak na etap ewolucji królestwa zwierząt. „Podstawowym przedmiotem refleksji [socjobiologii] jest proces ewolucji — pisze Gdula (2009, s. 30) — [...] Ewolucja jest procesem opartym na nieciągłości i lokalnych wynalazkach adaptacyjnych. Wygrać wcale 
nie muszą ani silniejsi, ani więksi. Wygrają ci, którym uda się przeżyć w zmiennych warunkach". Co ważne, perspektywa socjobiologiczna widzi mechanizmy kierujące życiem i światem, ale nie dostrzega ich ostatecznego celu ani sensu. $Z$ tej perspektywy człowiek nie kreuje własnego losu, lecz jedynie próbuje przetrwać i zapewnić przetrwanie swoim genom. Miłość natomiast stanowi zmiękczenie owej brutalnej prawdy o rzeczywistości ewolucyjnie-deterministycznej. Dzięki miłości romantycznej człowiek może mieć złudne poczucie sensu życia. Jednak zgodnie $z$ tą koncepcją miłość romantyczna nie jest niczym więcej jak procesem biochemicznym zachodzącym w organizmie.

Druga koncepcja przedstawia miłość jako pochodną struktury społecznej. Stanowi ona element szerszej teorii socjologicznej zaproponowanej przez Pierre'a Bourdieu (2005), zgodnie z którą jednostka żyje w społeczeństwie, działa jednak w ramach tak zwanych pól, czyli wycinków struktury społecznej, w których jednostki mają podobne dążenia, określające rywalizację między nimi. W myśl tej teorii człowiek dysponuje habitusem, czyli pewnym zestawem trwałych dyspozycji opartych na doświadczeniu, takich jak sposoby postrzegania świata czy reguły myślenia i postępowania. Według Bourdieu, klasowość nie jest wycinkiem rzeczywistości społecznej, ale jej fundamentem, istotą, przejawiającą się nawet w intymnych momentach życia ludzkiego. Miłość, zwana również „miłością przeznaczenia”, daje „poczucie idealnego dopasowania, rozumienia się bez słów [...] dzięki harmonii klasowo uwarunkowanych habitusów kochanków" (Gdula 2009, s. 46).

W trzeciej koncepcji, Niklasa Luhmanna, miłość rozumiana jest jako medium, które $z$ natury „nie jest uczuciem, lecz kodem komunikacyjnym, zgodnie z którym ludzie uczucia wyrażają, kształtują, stymulują, zakładają u innych, wypierają się ich i liczą ze wszystkimi konsekwencjami, jakie będzie mieć urzeczywistnienie określonego komunikatu" (Luhmann 2003, s. 21). Uczucia są tutaj swego rodzaju przekaźnikiem treści. Każda akcja powoduje reakcję. Miłość romantyczna stanowi płaszczyznę komunikowania się ludzi między sobą. Taka perspektywa pozwala badać zachowania interpersonalne generowane przez miłość. Taką perspektywę przyjmuje również Eva Illouz, która wskazuje na fakt wykorzystania w kapitalizmie miłości romantycznej (Illouz1997) oraz całej sfery emocjonalnej człowieka (Illouz 2010), na przykład w reklamach produktów.

Czwarta koncepcja prezentowana przez Gdulę to Zygmunta Baumana spojrzenie fenomenologiczne. Myśliciel ten porównuje ze sobą miłość i śmierć. Śmierć przytrafia się tylko raz w życiu, miłość natomiast, choć można doświadczyć jej wielokrotnie, za każdym razem jest zjawiskiem 
nieprzewidywalnym i przeżywanym tak, jakby była jedyna w swoim rodzaju. Bauman z jednej strony zauważa, że w dzisiejszych czasach miłość bywa nazywana praktyką, której można nauczyć się wraz z doświadczaniem uczuć i relacji miłosnych. Z drugiej natomiast strony pisze: „Do natury miłości należy, iż [...] jest ona zakładnikiem losu” (Bauman 2006, s. 16). Bauman zwraca uwagę na zmiany w społecznym postrzeganiu miłości romantycznej. Liberalizacja kultury spowodowała rozluźnienie więzów rodzinnych i, co za tym idzie, coraz więcej osób żywi przekonanie, że romantyczna miłość „do grobowej deski” nie istnieje. W zamian za to przelotny seks nazywany jest często „uprawianiem miłości”. Bauman nie znajduje precyzyjnej odpowiedzi na pytanie, czym tak naprawdę jest miłość romantyczna. W zamian proponuje perspektywę zmieniającej się, płynnej rzeczywistości w nowoczesnych czasach, w których tajemnica stanowi swego rodzaju istotę zarówno miłości, jak i śmierci.

Sam Maciej Gdula (2009) na podstawie własnych badań poradników eksperckich wyróżnia trzy dyskursy o miłości. „Dyskurs utopijny” charakteryzuje głównie to, że relacja miłosna jest w nim uważana przez aktorów społecznych za ważną dla niej samej. „Dyskurs utylitarny” uzasadnia istnienie relacji wydajnością w dostarczaniu partnerom przyjemności. $Z$ kolei „dyskurs tradycyjny” opiera się na kolektywnym postrzeganiu związku małżeństwa, którego celem jest prokreacja i wychowanie dzieci w tzw. pełnej rodzinie, a także przekazanie im wartości tego dyskursu. Na gruncie tego dyskursu jednostka jest zobowiązana do walki o nierozerwalność związku.

Anthony Giddens (2006) analizuje relacje miłosne oparte na intymności seksualnej i zaangażowaniu emocjonalnym. Patrzy on na miłość interpersonalną ( $w$ takich relacjach) $z$ perspektywy procesu liberalizacji seksualnej i tworzy własną koncepcję teoretyczną tzw. czystej relacji, stanowiącą swego rodzaju weberowski typ idealny więzi społecznej nowoczesności. Dla aktorów interakcji jest ważna ze względu na utylitarną wartość emocjonalną, którą im daje. Gdy relacja przestaje zaspokajać potrzeby aktorów, wypala się i przestaje mieć wartość, co prowadzi do jej zakończenia. Giddens wyodrębnia trzy rodzaje miłości. „Miłość namiętna” opiera się na intensywnej więzi seksualnej, pożądaniu oraz wyidealizowaniu atrakcyjności fizycznej partnera. W „miłości romantycznej” idealizacja zostaje przeniesiona na jego charakter. Powoduje to głębokie zadurzenie już nie tylko w sferze fizycznej atrakcyjności wynikającej z pragnienia rozkoszy i spełnienia seksualnego, ale głównie w wyidealizowanej osobowości ukochanego, z którym pragniemy spędzić życie, naiwnie myśląc, że będzie „usłane różami”. „Miłość współbieżna” natomiast jest połączeniem 
dwóch poprzednich rodzajów miłości w relacji traktowanej czysto utylitarnie. Trwa ona dopóty, dopóki zadurzenie emocjonalne jest intensywne. Gdy uczucie słabnie, relacja się rozpada. To właśnie ten rodzaj miłości stanowi przejaw wykorzystania teoretycznego konstruktu „czystej relacji” w praktyce i, zdaniem Giddensa, jest „najzdrowszym” typem miłości we współczesnym społeczeństwie.

\section{KONCEPCJA MIŁOŚCI ROMANTYCZNEJ HALWANIEGO}

Raja Halwani, profesor filozofii w School of the Art Institute of Chicago, swoją koncepcję miłości romantycznej przedstawił w książce Philosophy of Love, Sex, and Mariage: An Introduction (2018) ${ }^{1}$. Miłość romantyczna w ujęciu Halwaniego jest wyodrębnionym rodzajem miłości, zdefiniowanym w bardzo ogólny sposób jako miłość interpersonalna dwóch niespokrewnionych osób (niezależnie od orientacji seksualnej) połączonych więzią emocjonalną. Wyodrębnienie terminu "miłość romantyczna” z całego pola semantycznego pojęcia miłości jest niewątpliwie wskazane w imię precyzji i zwięzłości. Jednak — według zasad logiki formalnej - gdy konceptualizujemy pojęcie o węższym znaczeniu, wyodrębnione z pojęcia szerszego znaczeniowo, pierwsze pytanie powinno dotyczyć konceptualizacji pojęcia pierwotnego, czego niestety w książce Halwaniego brakuje. Może to prowadzić do nieświadomego lub świadomego przeinaczenia pola konotacyjno-denotacyjnego węższego znaczeniowo pojęcia „miłość romantyczna”.

Na początku swoich rozważań Halwani definiuje miłość romantyczną za pomocą terminu an emotion. Nie operacjonalizuje jednak pojęcia „emocja” w sposób naukowy. Pisze, co prawda, że emocje składają się zarówno z myśli, przekonań, jak i z uczuć (Halwani 2018, s. 17). Czyni to jednak bez żadnych naukowych podstaw czy odwołań. Ponadto w takim stwierdzeniu brakuje precyzji. Autor nie opisuje relacji między przekonaniem a uczuciem. Nie wiadomo nawet, czy w takim konstrukcje rozumiemy emocję w kategoriach afektu, działającego na zasadach „bezpośredniej regulacji zachowań”(Kolańczyk 1998), czy „uczucia głębokiego” (Szewczuk 1998, s. 250), będącego skomplikowanym, złożonym stanem psychofizycznym. Zabieg taki rzutuje na całą koncepcję miłości romantycznej autora i prowadzi do powstania wielu sprzeczności logicznych w toku analiz. Na przykład

\footnotetext{
${ }^{1}$ Inne prace tego autora to: Virtuous Liaisons: Care, Love, Sex, and Virtue Ethics (2003) oraz z zakresu filozofii polityki The Israeli-Palestinian Conflict: Philosophical Essays on Self-Determination, Terrorism and the One-State Solution (Halwani, Kapitan 2010).
} 
w podsumowaniu rozdziału „Miłość i moralność” Halwani (2018, s. 115) pisze, o miłości romantycznej jako o relacji. Czyżby zatem utożsamiał pojęcie „stan emocjonalny” z pojęciem „relacja”? Jest to o tyle istotne, że emocja, czy nawet stan emocjonalny, składający się z wielu (korespondujących ze sobą) emocji, to subiektywna, intrapersonalna, psychiczna właściwość człowieka. W takiej definicji miłości - być może skutecznej na gruncie psychologii — brakuje jasno wyodrębnionego wymiaru społecznego. Sprawia to, że jest ona myląca, gdy wchodzimy w przestrzeń relacji interpersonalnych, trudno też porównywać ją z innymi koncepcjami miłości, takimi jak popularne stanowisko przyjęte przez nurt personalizmu chrześcijańskiego (Granat i in. 2018; Wojtyła 2010) czy koncepcja Ericha Fromma (2018), który definiuje miłość jako czynną postawę podejścia do drugiego człowieka.

Halwani (2018, s. 20-23) rozróżnia - ze względu na charakter więzi - dwa rodzaje miłości romantycznej. Romantic Love 1 (RL1) można przyrównać do uczucia zauroczenia drugą osobą, w którym patrzy się na obiekt swojego zakochania przez pryzmat jego atrakcyjności. Jest to bardzo egoistyczne spojrzenie na „przedmiot miłości”, gdyż najważniejsze jest spełnienie własnych pragnień/potrzeb. W tym typie romantycznej miłości (lub też jej pierwszym stadium) bardzo ważną, jeśli nie najważniejszą, rolę odgrywa pociąg seksualny oparty na atrakcyjności kochanka/kochanki. Ten typ miłości romantycznej koresponduje bezpośrednio z koncepcją amour passion Anthony'ego Giddensa. Z kolei Romantic Love 2 (RL2) bazuje na uczuciu troski względem drugiej osoby. Ten rodzaj miłości romantycznej związany jest $z$ aktem intelektualnego i emocjonalnego poznania partnera/partnerki prowadzącym do poczucia przyzwyczajenia się do jego/jej obecności. Zakochani poznają mniej atrakcyjne informacje na swój temat (np. o swoich słabościach, problemach) i decydują się na ich akceptację. W procesie trwania relacji następuje przenikanie się osobowości oraz „docieranie się” charakterów zakochanych. Osoby zakochane przestają patrzeć na otaczająca je rzeczywistość w czysto egocentryczny sposób (z punktu widzenia Ja), a zaczynają żyć w swego rodzaju wspólnocie, która staje się pryzmatem obserwacji siebie i świata.

Halwani (2018, s. 11-20) przedstawia różne perspektywy postrzegania miłości romantycznej jako zjawiska biologicznego albo nieemocjonalnego, i polemizuje z nimi. Rozpoczyna od podejścia neurobiologicznego, korespondującego, a może nawet utożsamianego z koncepcją socjobiologiczną. Na gruncie tego podejścia miłość romantyczną tłumaczy się jako sekwencję wydzielania się hormonów, co powoduje psychosomatyczne odczucia intelektualno-emocjonalne. Halwani przytacza twierdzenie Carrie Jenkins 
(2017), że aby poznać i, co za tym idzie, zrozumieć zjawisko miłości romantycznej, musimy przyjrzeć się zarówno procesom neurobiologicznym prowadzącym do stanu emocjonalnego, czyli uczucia zakochania, jak i spojrzeć na to zjawisko z punktu widzenia obserwatora społecznego, by dostrzec mechanizmy relacji interpersonalnych towarzyszących miłości romantycznej. Halwani, zgadzając się z Jenkins, że miłość romantyczna ma podwójną, biologiczno-społeczną naturę, zaznacza, że nawet przy całkowitym wyjaśnieniu miłości romantycznej na płaszczyźnie neurobiologicznej, czy też socjobiologicznej, nadal pozostaje niezrozumiała filozoficzno-społeczna istota tego pojęcia.

Na gruncie drugiej koncepcji przedstawionej przez Halwaniego miłość romantyczną definiuje się jako pragnienie/pożądanie lub też zbiór pragnień (a set of desires) nieuzasadnionych zdefiniowanymi przekonaniami (Green 1997). Halwani zgadza się $z$ tą koncepcją częściowo. Jego zdaniem, można ją zastosować jedynie w odniesieniu do RL1, która z natury jest czystym pożądaniem niepopartym uświadomioną przyczyną. RL2 natomiast opiera się na poznaniu zarówno zalet, jak i wad partnera. „Decydując się” na RL2 mamy logiczne i przynajmniej częściowo uświadomione powody bycia zakochanym.

Halwani nie zgadza się także ze stwierdzeniem Roberta Solomona (Solomon, Higgins 1991), że miłość (w tym miłość romantyczna) jest cnotą, pisząc, że miłość romantyczna, jako taka, nie jest ani moralnie pozytywna, ani negatywna. Nie zgadza się również z twierdzeniem Rolanda de Sousy (2015, s. 3-4), że miłość nie może być emocją, ponieważ emocja jest prostym, jednorodnym sygnałem, a miłość przejawia się pod postacią różnych emocji i dlatego jest definiowana jako warunek lub syndrom. Ta perspektywa koresponduje, jak się wydaje, z koncepcją miłości zaproponowaną przez Niklasa Luhmanna, w której miłość jako medium (kod komunikacyjny) stanowi płaszczyznę przejawiania się i tworzenia emocji.

Ostatnią z perspektyw, przywołanych przez Halwaniego, jest koncepcja Aarona Smutsa, w której miłość romantyczna utożsamiana jest z troską, będącą nie emocją, ale fundamentem, na którym emocje się kształtują. Halwani zgadza się, że troska może być płaszczyzną, na której emocje powstają, ale błędem jest, jego zdaniem, utożsamienie miłości romantycznej, w szczególności RL1, z pojęciem troski.

Jeśli weźmie się pod uwagę przedstawione wyżej koncepcje, a zwłaszcza te elementy, z którymi Halwani się zgadza, to jego twierdzenie, że miłość romantyczna jest stanem emocjonalnym, wydaje się łatwe do podważenia. Z jednej strony Halwani zgadza się, że RL1 nie opiera się na przekonaniach, przez co nie powinna być definiowana jako stan emocjo- 
nalny, lecz jako zbiór pragnień i namiętności. Z drugiej strony twierdzi, że RL2 polega głównie na trosce o ukochaną osobę. Troska natomiast nie jest stanem emocjonalnym. Wynika więc $z$ tego, że RL2 również nim nie jest, a osoba zakochana może odczuwać wiele emocji, cały czas będąc zakochaną. Taka argumentacja podważa główne twierdzenie zawarte w książce Philosophy of Love, Sex, and Marriage: An Introduction, że miłość romantyczna jest stanem emocjonalnym.

Halwani (2018, s. 47-77) wymienia i opisuje cechy, które - jego zdaniem - są powszechnie utożsamiane z miłością romantyczną. Są to: ekskluzywność połączona z wyłącznością, stałość, unikatowość i niezastępowalność ukochanego/ukochanej, wspólnotowość, silna troska o ukochanego/ukochną, pożądanie i aktywność seksualna, bliskość fizyczna i emocjonalna, tęsknota oraz ból w przypadku straty ukochanej osoby. W takich kategoriach, jego zdaniem, ludzie myślą o miłości. Jednakże, jak sądzę, występuje pewna różnica między miłością romantyczną a stanami emocjonalnymi. Miłość romantyczna wydaje się o wiele bardziej złożona. Sam Halwani pisze, że podane przezeń cechy, nie wystarczają do jednoznacznego opisu miłości romantycznej. Większość z cech przypisywanych przez Halwaniego miłości romantycznej charakteryzuje nie tylko ten typ miłości, ale również inne jej rodzaje, a nawet przyjaźń. Niektóre natomiast charakteryzują tylko jeden rodzaj miłości romantycznej, na przykład pożądanie — RL1, a poczucie silnej troski — RL2.

\section{MIŁOŚĆ ROMANTYCZNA A MORALNOŚĆ}

Przejdźmy do sfery etyki, która również stanowi istotny aspekt koncepcji Halwaniego, Pisze on, że miłość romantyczna, jako zjawisko, ze względu na emocjonalny charakter nie poddaje się ocenie moralnej. Dopuszcza jednak moralną ocenę działań osoby zakochanej. Problem polega na kryterium owej oceny. Jeśli założymy, że największą wartością dla zakochanej osoby jest faktycznie doświadczane poczucie zakochania i bycia kochanym, to działania umotywowane uczuciem miłości lub też podjęte przez wzgląd na tę miłość są subiektywnie usprawiedliwiane. Wyłania się więc obraz relatywnej oceny moralnej, co wynika z subiektywnej perspektywy działań, które są umotywowane dążeniem do najwyższego dobra, jakim jest doświadczanie miłości romantycznej - wybuchowej, płomiennej, górnolotnej i przesiąkniętej duchem epoki romantyzmu. Romantyzm - jak pisze Maria Ossowska (2005, s. 98) - „widział ścisłą zależność między kształceniem wrażliwości moralnej i wrażliwości estetycznej”, która w dużej mierze ma podłoże emocjonalne. Omawiając zawiązek między 
miłością romantyczną a moralnością, Halwani sięga do trzech teorii etycznych: konsekwencjonalizmu (utylitaryzmu), etyki kantowskiej oraz etyki cnót.

Według The Stanford Encyclopedia of Philosophy „[...] działanie jest moralnie słuszne, [...] wtedy i tylko wtedy, gdy całkowita kwota dobra dla wszystkich minus całkowita kwota zła dla wszystkich [wynikająca $z$ tego działania] jest większa niż [owa] kwota netto wszystkich innych działań, możliwych do wykonania w danej sytuacji” (Sinnott-Armstrong 2015). Halwani (2018, s. 98-99) sięga do stanowiska klasycznego utylitary$\mathrm{zmu}^{2}$, opartego na hedonistycznym konsekwencjonalimie, który utożsamia szczęście z przyjemnością. Warto jednak odróżnić postawę hedonisty praktykującego, który nie musi rozumowo utożsamiać się z poglądem psychologiczno-etycznym, lecz daje przykłady takiej postawy, od postawy głosiciela poglądów hedonistycznych, który nie musi zgodnie z nimi postępować (Ossowska 1949, s. 46). Halwani wskazuje, że poza oczywistymi korzyściami z bycia zakochanym miłość romantyczna prowadzi również do takich negatywnych skutków jak ból z powodu straty, oszustwa czy kłamstwa. Co więcej, tzw. niespełniona miłość może prowadzić do wielu działań uznanych społecznie za patologiczne. Tego typu mechanizmy działania opisała na przykład Karen Horney w Neurotycznej osobowości naszych czasów (1968). Jednak etyka — jak pisze Halwani - dopuszcza indywidualne dążenie do miłości, a samą miłość romantyczną, jako stan emocjonalny, uznaje za dozwoloną, pod warunkiem, że jest ona zgodna z wyżej wymienioną ogólną zasadą moralną.

Warto przywołać tutaj pryncypialną krytykę hedonistycznego utylitaryzmu sformułowaną przez Karola Wojtyłę (2010, s. 38): „Przyjemność $z$ istoty swojej jest czymś ubocznym, przypadłościowym, czymś, co może pojawić się przy sposobności działania. $Z$ natury rzeczy więc organizowanie tegoż działania pod kątem przyjemności jako wyłącznego lub najwyższego celu kłóci się z właściwą budową ludzkich czynów". Według Wojtyły miłość jest zjednoczeniem osób na wszystkich możliwych płaszczyznach (fizycznej, intelektualnej, emocjonalnej oraz duchowej), co może odbyć się jedynie „[...] poprzez uznanie poza dobrem czysto subiektywnym, tj. poza przyjemnością, dobra obiektywnego, które może jednoczyć osoby i wówczas nabiera cech dobra wspólnego" (Wojtyła 2010, s. 40). Utylitaryzm natomiast konfrontuje egoizmy poszczególnych osób. Jeśli nawet

2 Utylitaryzm jest poglądem dotyczącym „[...] oceniania i przybierający[m] czasem postać twierdzenia z zakresu psychologii oceniania, kiedy indziej zaś postać dyrektywy wskazującej jak oceniać należy" (Ossowska1966a, s. 297). 
zostanie podjęta próba ich synchronizacji, to „egoizmy - czytamy dalej (Wojtyła 2010, s. 40) - pozostaną w tej harmonizacji nadal egoizmami, z tym tylko, że te dwa egoizmy, kobiecy i męski, będą dla siebie wzajemnie przydatne i wzajemnie korzystne".

Etyka kantowska, inaczej niż konsekwencjonalizm, skupia się na intencjach działań, a nie na samych działaniach. Gdy na przykład znajdę zagubionego psa i postanawiam zwrócić go właścicielowi, to ważne są moje pobudki. W etyce kantowskiej człowiek powinien kierować się jedynie zasadami etycznymi, ich realizacja powinna być zawsze celem naszych intencji i wynikających z nich działań, które nie powinny być środkiem wykorzystanym do osiągnięcia innego celu. Maria Ossowska, analizując ten model etyczny, wskazuje trzy czynniki odróżniające działanie wobec drugiego człowieka podyktowane intencją, w której jest on celem tego działania, od działania, podyktowanego intencją użycia drugiego człowieka do osiągnięcia innego celu. Czynnikami tymi są: „[...] zaprzęgnięcie człowieka do swoich celów bez liczenia się z jego celami, jego niewiedza o tym, że jest tak właśnie traktowany, jego uprawomocnione w tej sytuacji oczekiwanie, że stosunek działającego do niego jest stosunkiem liczącym się z jego hierarchią wartości i jego potrzebami" (Ossowska 1949, s. 170). Najważniejszą zasadą tego modelu etycznego jest tak zwany imperatyw kategoryczny, „Postępuj wedle takiej tylko zasady, co do której mógłbyś jednocześnie chcieć, aby stała się prawem powszechnym" (Kant 2002, s. 60). Maria Ossowska, nawiązując do owej „kantowskiej powszechności”, pisze przewrotnie, że bezstronność, uważana przez Davida Hume'a, Kurta Baiera i wielu filozofów moralności za podstawowe kryterium prawidłowej, dającej się uogólnić, oceny moralnej „[...] nie należy [...] do dyspozycji powszechnych, co by znowu ograniczało wypowiadanie ocen moralnych"(Ossowska 1966b, s. 26). Miłość romantyczna, rozumiana jako subiektywne, emocjonalne zjawisko, sama w sobie nie jest i nie może być bezstronna. Dlatego — zdaniem Halwaniego (2018, s. 99-102) - etyka kantowska nie nakazuje miłości romantycznej, ale dopuszcza ją pod warunkiem, że spełnia ona powyższe kryteria.

Etyka cnót opiera się na założeniu, że istnieją szczególnie pożądanecechy ludzkie, zwane cnotami. Halwani (2018, s. 103) przytacza definicję cnoty według Arystotelesa, który pisał w Etyce nikomachejskiej: „Jest tedy dzielność etyczna pewnego rodzaju umiarem, skoro zmierza do środka jako do swego celu" (Arystoteles 2012, s. 112). Halwani twierdzi, że ten rodzaj etyki również przyzwala na miłość romantyczną, o ile nie powoduje ona zaciemnienia świadomości prowadzącego do rezygnacji z bycia człowiekiem cnotliwym. 
Halwani w podsumowaniu rozważań na temat trzech wskazanych wyżej systemów etycznych pisze, że miłość romantyczna (rozumiana jako stan emocjonalny) jest przez nie dopuszczana lub też usprawiedliwiana, choć jednocześnie wytyczane są pewne ramy, poza które człowiek zakochany wychodzić nie powinien. Wskazuje na kilka zasad dotyczących zachowań osoby zakochanej wobec ukochanego/ukochanej, a także wierzeń/wartości. Osoba zakochana powinna być szczera, nie krzywdzić ukochanego/ukochanej, utrzymywać ukochanego/ukochaną w dobrym samopoczuciu, dotrzymywać obietnic oraz wspierać go/ją w dążeniu do celów. Ponadto Halwani wskazuje na istotność aspektu seksualnego w miłości romantycznej - pisze, że jeżeli obie strony nie zdecydują inaczej, to powinny dążyć do sprawiania sobie przyjemności na tym poziomie. Jeśli którakolwiek strona tego nie czyni, druga ma prawo zakończyć relację.

\section{PODSUMOWANIE}

Skoro stan emocjonalny jest zwykle odczuwany i przeżywany indywidualnie przez jednostkę ${ }^{3}$, to jej tymczasowa moralność, podporządkowana temu stanowi, nie musi pokrywać się z ramami moralnymi innych osób. Osoba zakochana patrzy na otaczający ją świat i społeczeństwo w sposób egoistyczny. Co więcej, nawet w związku miłosnym stany emocjonalne osób zakochanych nie muszą być jednakowe. Dlatego też pragnienie dobra dla ukochanej osoby, ujęte subiektywnie, nie musi pokrywać się z tym, co umiłowany uważa za dobro dla siebie.

Raja Halwani (2018) przedstawia koncepcję, według której miłość romantyczna jest stanem emocjonalnym. Koncepcja tego rodzaju, rzadko występująca $\mathrm{w}$ polskiej socjologii, pojawia się w pracach Anthony'ego Giddensa, Zygmunta Baumana czy Evy Illouz. Jest to jednak, w moim mniemaniu, ujęcie fragmentaryczne. „Miłość — jak pisze Elżbieta Hałas (1996, s. 190) - [...] wymaga wyjaśnienia i usprawiedliwienia jako temat socjologiczny. Gdyby była tylko uczuciem, irracjonalnym impulsem, niewytłumaczalną tajemnicą, nie mogłaby być badana przez socjologów. Jednakże podejmują oni to zagadnienie [...]".

Jak stwierdziłem wcześniej, miłość, w tym miłość romantyczna, jest badana jako zjawisko i opisywana przez wielu socjologów. W większości przypadków wpisuje się ona w większe teorie życia społecznego, jak u Pierre'a Bourdieu (teoria przemocy symbolicznej) czy Niklasa Luhmanna (teoria kodu komunikacyjnego). W zależności od tego, jaką perspek-

\footnotetext{
${ }^{3}$ Nie dotyczy to emocji przekazywanych w tłumie (Le Bon 1986).
} 
tywę przyjmuje badacz w stosunku do reguł rządzących społeczeństwem, w taki też sposób ujęta zostanie koncepcja miłości, wpisująca się w realia dynamiki społecznej.

Gdy spojrzymy na miłość romantyczną przez pryzmat koncepcji Halwaniego, to możemy zauważyć kilka nieścisłości metodologicznych.

Po pierwsze, co wydaje się kwestią najważniejszą, miłość romantyczna zdefiniowana jako stan emocjonalny trudna jest do analizy w rzeczywistości społecznej. Emocja, ze swej natury, jest fenomenem subiektywnym, przeżywanym wewnętrznie, psychicznie. Interakcja jest natomiast fenomenem społecznym. Jeśli zamkniemy miłość romantyczną jedynie $\mathrm{w}$ intrapersonalnej sferze emocji człowieka, to w jaki sposób wytłumaczymy miłość romantyczną przejawiającą się - jako zjawisko społeczne - w relacjach interpersonalnych? Fakt, że można mówić o „relacji miłosnej”, sam w sobie sugeruje, że miłość romantyczna jest właśnie zjawiskiem społecznym. Oczywiście ma ona podłoże emocjonalne, jednak jest przeżywana dopiero w procesie interakcji, na którą poza emocjami składają się decyzje uwidocznione $\mathrm{w}$ działaniach podejmowanych na tle interpersonalnym.

Po drugie, niedoprecyzowanie pojęcia „miłość (sensu largo) skutkuje niejasnym wydzieleniem $z$ niego pojęcia "miłość romantyczna”. Niesie to bardzo poważne konsekwencje w trakcie późniejszego charakteryzowania i opisywania, jakimi przymiotami charakteryzuje się miłość romantyczna i czym tak naprawdę różni się od innych rodzajów miłości. Jest to ważne zarówno w procesie operacjonalizacji pojęcia, analizy dynamiki społecznej oraz w trakcie badania norm moralnych, jakimi kieruje się osoba zakochana.

Po trzecie, problemem miłości romantycznej, gdy patrzymy na nią jak na stan emocjonalny, jest sfera moralności. Nie możemy oceniać moralnie stanu emocjonalnego. Kształtuje on jednak nasze priorytety, tworząc subiektywną moralność opartą na uczuciu zakochania. Gdy miłość (w tym zachowania względem partnera i otoczenia) sprowadzimy do stanu emocjonalnego, trudno jest mówić o ocenie moralnej czynów osoby zakochanej, bo jej subiektywne normy moralne, podyktowane priorytetami określanymi przez stan emocjonalny zakochania, są inne (subiektywne) niż ogólnie przyjęte normy społeczne otoczenia. Przedstawię to na przykładzie innej emocji. Gdy stanem emocjonalnym nazywamy gniew, to nie możemy go oceniać z moralnego punktu widzenia, gdyż emocje nie podlegają ocenie moralnej. Jednak dysponujemy również pojęciem agresji, która jest oparta na gniewie. Nie jest już jednak emocją, dlatego podlega ocenie moralnej, a nawet prawnej.

Halwanii mówi o napięciu między punktem widzenia osoby zakochanej a innymi punktami widzenia. Pytanie brzmi, czy w koncepcji miłości 
zdefiniowanej jako stan emocjonalny w ogóle istnieje jakiekolwiek miejsce na zewnętrzną (intersubiektywną) ocenę zachowań osoby zakochanej?

Reasumując: koncepcja przedstawiająca miłość romantyczną jako stan emocjonalny może być interesująca zarówno dla psychologa, jak i dla filozofa. Jednak z socjologicznego punktu widzenia widać, jakie braki i nieścisłości ma ona, gdy miłość jest rozpartywana w perspektywie dynamiki społecznej. Ważne jest, by nie zapominać o emocjonalnym podłożu miłości romantycznej, jednak zamknięcie jej w sferze czysto emocjonalnej wydaje się błędem metodologicznym.

\section{BIBLIOGRAFIA}

Arystoteles, 2012, Etyka nikomachejska, tłum. Daniela Gromska, Wydawnictwo Naukowe PWN, Warszawa.

Bauman Zygmunt, 2006, Razem, osobno, tłum. Tomasz Kunz, Wydawnictwo Literackie, Kraków.

Bourdieu Pierre, 2005, Dystynkcja. Społeczna krytyka władzy sądzenia, tłum. Piotr Biłos, Scholar, Warszawa.

De Sousa Ronald, 2015, Love: A Very Short Introduction, Oxford University Press, Oxford UK. Encyklika, 2006, Encyklika: Deus Caritas Est Ojca Świętego Benedykta XVI do biskupów, prezbiterów i diakonów, do osób konsekrowanych i wszystkich wiernych świeckich o mitości chrześcijańskiej, Pallottinum, Poznań.

Fromm Erich, 2018, O sztuce miłości, tłum. Aleksander Bogdański, Rebis, Poznań.

Gdula Maciej, 2009, Trzy dyskursy miłosne, Oficyna Naukowa, Warszawa.

Giddens Antony, 2006, Przemiany intymności. Seksualność, miłość i erotyzm we wspótczesnych społeczeństwach, tłum. Alina Szulżycka, Wydawnictwo Naukowe PWN, Warszawa.

Granat Wincenty, Szumił Halina Irena, Napiórkowski Stanisław Celestyn, Guzowski Krzysztof, Barth Grzegorz, 2018, Personalizm chrześcijański: Teologia osoby ludzkiej, Wydawnictwo Diecezjalne i Drukarnia w Sandomierzu, Sandomierz.

Green O. Harvey, 1997, Is Love an Emotion?, w: Roger E. Lamb (red.), Love Analyzed, Westview Press, Boulder, Colo.

Halwani Raja, 2003, Virtuous Liaisons: Care, Love, Sex, and Virtue Ethics, Open Court, Chicago, Ill.

Halwani Raja, 2018, Philosophy of Love, Sex and Marriage: An Introduction, Routledge, New York. Halwani Raja, Kapitan Tomis, 2010, The Israeli-Palestinian Conflict: Philosophical Essays on Self-Determination, Terrorism and the One-State Solution, Palgrave Macmillan, New York.

Hałas Elżbieta, 1996, Małżeństwo a kulturowe modele miłości, „Roczniki Nauk Społecznych”, t. $24, z .1$.

Horney Karen, 1968, Neurotyczna osobowość naszych czasów, tłum. Helena Grzegołowska, Państwowe Wydawnictwo Naukowe, Warszawa.

Illouz Eva, 1997, Consuming the Romantic Utopia: Love and the Cultural Contradictions of Capitalism, University of California Press, Berkeley.

Illouz Eva, 2010, Uczucia $w$ dobie kapitalizmu, tłum. Zygmunt Simbierowicz, Oficyna Naukowa, Warszawa. 
Jenkins Carrie, 2017, What Love Is and What It Could Be, Basic Books, New York.

Kant Immanuel, 2002, Uzasadnienie metafizyki moralności, tłum. Mścisław Wartenberg, Altaya Polska, Warszawa.

Katechizm, 2018, Katechizm Kościoła Katolickiego, Pallottinum, Poznań.

Kolańczyk Alina, 1998, Czuję myśle jestem. Świadomość i procesy psychiczne w ujęciu poznawczym, Gdańskie Wydawnictwo Psychologiczne, Gdańsk.

Le Bon Gustaw, 1986, Psychologia tłumu, tłum. Bolesław Kaprocki, Państwowe Wydawnictwo Wydawnictwo Naukowe, Warszawa.

Borgatta Edgar F., Montgomery Rhonda J.W. (red.), 2000, Encyclopedia of Sociology, Macmillan, New York.

Luhmann Niklas, 2003, Semantyka miłości. O kodowaniu intymności, tłum. Jerzy Łoziński, Scholar, Warszawa.

Ossowska Maria, 1949, Motywy postępowania. Z zagadnień psychologii moralności, Książka i Wiedza, Warszawa.

Ossowska Maria, 1966a, Pojęcie moralności, „Etyka”, nr 1, s. 19-29.

Ossowska Maria, 1966b, Myśl moralna oświecenia angielskiego, Państwowe Wydawnictwo Naukowe, Warszawa.

Ossowska Maria, 2005, Socjologia moralności zarys zagadnień, Wydawnictwo Naukowe PWN, Warszawa.

Sinnott-Armstrong Walter, 2015, Consequentialism, w: The Stanford Encyclopedia of Philosophy (https://plato.stanford.edu/archives/win2015/entries/consequentialism).

Solomon Robert C., Higgins Kathleen M. (red.), 1991, The Philosophy of (Erotic) Love, University Press of Kansas, Lawrence, Kan.

Szewczuk Włodzimierz (red.), 1998, Encyklopedia psychologii, Fundacja Innowacja, Warszawa. Wojtyła Karol, 2010, Miłość i odpowiedzialność, Towarzystwo Naukowe KUL, Lublin.

\title{
IS ROMANTIC LOVE AN EMOTION?
}

\author{
Michał Dąbrowski \\ (Institute of Political Studies PAS, The Maria Grzegorzewska University)
}

\section{Abstract}

The aim of this article is to analyze Raja Halwani's concept of "romantic love." Her main thesis is that romantic love is an emotion. The author of the article tries to look at the concept from the perspective of the social sciences, juxtaposing it with selected notions of romantic love from the border of sociology, social philosophy, and theology. He considers that the approach according to which romantic love is presented as an emotional state may be interesting not only for the psychologist but also for the philosopher or sociologist. He points out that love as an emotion is not subject to moral judgments. Finally, he concludes that when considering romantic love from a sociological point of view, its emotional basis should not be overlooked, but closing the phenomenon in the purely emotional sphere seems to be a methodological error. 
key words: love, romantic love, sociology of love, sociology of emotions, Raja Halwani

stowa kluczowe: miłość, miłość romantyczna, socjologia miłości, socjologia emocji, socjologia rodziny, Raja Halwani 